\title{
ANALISIS KEMAMPUAN LITERASI DIGITAL MAHASISWA
}

\author{
Karsoni Berta Dinata
}

Pendidikan Matematika, Universitas Muhammadiyah Kotabumi

Jalan Hasan Kepala Ratu, Nomor1052 Kotabumi, Lampung Utara, Lampung e-mail: karsoni.bertadinata@gmail.com

\begin{tabular}{cccc} 
Submitted & Accepted & Published \\
$2021-03-16$ & $2021-05-06$ & $2021-05-12$ & OPEN \\
\hline
\end{tabular}

Pandemi COVID-19 menyebabkan terjadinya perubahan proses pembelajaran dari tatap muka langsung menjadi pembelajaran daring yang memerlukan kemampuan literasi digital. Penelitian bertujuan untuk mengetahui bagaimana kemampuan literasi digital mahasiswa. Metode penelitian yang digunakan adalah deskriptif kuantitatif. Populasi penelitian adalah seluruh mahasiswa semester 7 Program Studi Pendidikan Matematika Fakultas Keguruan dan Ilmu Pendidikan Universitas Muhammadiyah Kotabumi tahun akademik 2020/2021 yang berjumlah 41 orang. Sampel penelitian sebanyak 30 orang yang diperoleh dengan menggunakan teknik simple random sampling. Data dikumpulkan dengan menggunakan angket kemampuan literasi digital. Teknik analisis data menggunakan statistik deskriptif. Hasil penelitian menunjukkan bahwa responden "Sangat Baik" pada kemampuan functional skill and beyond dan "Baik" pada ketujuh aspek literasi digital yang lain. Berdasarkan hasil analisis data, maka disimpulkan bahwa kemampuan literasi digital mahasiswa Program Studi Pendidikan Matematika Fakultas Keguruan dan Ilmu Pendidikan Universitas Muhammadiyah Kotabumi berada pada kategori "Baik".

Kata Kunci: literasi digital; pembelajaran daring; COVID-19.

\begin{abstract}
The COVID-19 pandemic has led to a change in the learning process from face-toface to online learning that requires digital literacy skills. This research aimed to determine how students' digital literacy skills were. The research method used was descriptive quantitative. The population in this study were all students of the Mathematics Education Study Program, Faculty of Teacher Training and Education, Muhammadiyah Kotabumi University in the 7th semester of the $2020 / 2021$ academic year, totaling 41 people. The research sample was 30 people who were obtained using simple random sampling technique. Data were collected using a digital literacy ability questionnaire. The data analysis technique used descriptive statistics. The results showed that the respondents were "Very Good" in their functional skills and beyond and "Good" in the other seven aspects of digital literacy. Based on the results of data analysis, it is concluded that the digital literacy skills of students in the Mathematics Education Study Program of the Teacher Training and Education Faculty, Muhammadiyah University of Kotabumi are in the "Good" category.
\end{abstract}

Keywords: digital literacy; e-learning; COVID-19.

\section{PENDAHULUAN}

Literasi digital adalah salah satu kemampuan yang mesti dikuasai oleh mahasiswa dalam rangka mempersiapkan diri menghadapi revolusi industri 4.0. 
Enam literasi dasar terdiri dari literasi baca-tulis, sains, numerasi, digital, finansial, serta budaya dan kewargaan. Karena pesatnya kemajuan Teknologi Informasi dan Komunikasi (TIK), menyebabkan kemampuan literasi digital, informasi, dan teknologi sama pentingnya dengan kemampuan umum yang lain (Fatmawati \& Safitri, 2020; Nurcahyo, 2020; Kemendikbud, 2017).

Pandemi COVID-19 telah berdampak signifikan terhadap proses pembelajaran di Universitas Muhammadiyah Kotabumi, Lampung. Tentu saja, hal tersebut berdampak juga terhadap proses pembelajaran di Program Studi Pendidikan Matematika Fakultas Keguruan dan Ilmu Pendidikan. Dampak yang sangat terasa adalah pada perubahan proses pembelajaran, dari proses pembelajaran tatap muka langsung menjadi pembelajaran daring. Berbagai penelitian telah dilakukan terkait pembelajaran di masa pandemi COVID-19, yang hasil penelitannya menyimpulkan bahwa masih perlunya perbaikan proses pembelajaran daring (Dwi et al., 2020; Dinata, 2020; Putria et al., 2020).

Proses pembelajaran daring menuntut mahasiswa agar belajar secara mandiri. Salah satu kemampuan yang berperan cukup penting dalam memfasilitasi belajar mandiri dan ikut menentukan keberhasilan belajar adalah kemampuan memanfaatkan TIK. Salah satu faktor penentu keberhasilan belajar adalah kemampuan dalam mencari informasi yang dibutuhkan di jejaring digital/internet (Fadila et al., 2021). Mahasiswa dengan kemampuan literasi digital yang baik akan berupaya untuk mencari/menyeleksi informasi yang penting serta memahami, mengkomunikasikan, dan menyampaikan gagasan-gasan di ruang digital. Dengan demikian, kemampuan literasi digital akan membuka kesempatan kepada mahasiswa untuk berpikir, berkomunikasi, dan berkarya yang akhirnya bermuara pada kesuksesan belajar (Sujana \& Rachmatin, 2019; Elpira, 2018).

Istilah literasi digital merupakan kemampuan seseorang dalam menggunakan piranti komputer untuk mengakses berbagai informasi di ruang digital (Gilster \& Watson, 1999). Terdapat 8 komponen literasi digital, yaitu: (1) Functional skill and beyond. Merupakan komponen literasi digital yang berkaitan dengan keahlian menggunakan teknologi informasi; (2) Creativity. Merupakan komponen literasi digital yang terkait dengan cara berpikir kreatif memanfaatkan 
Edukasi: Jurnal Pendidikan, Volume 19 Nomor 1 Tahun 2021

Analisis Kemampuan Literasi Digital Mahasiswa

Karsoni Berta Dinata

Halaman 105-119

TIK dalam membangun pengetahuan; (3) Collaboration. Merupakan komponen literasi digital yang terkait dengan membangun pengetahuan melalui proses diskusi dan saling memberikan masukan di ruang digital; (4) Communication. Merupakan komponen literasi digital yang terkait kemampuan mendengar, memahami, dan menyampaikan gagasan; (5) The ability to find and select infomation (memilih informasi); (6) Critical thinking and evaluation (berpikir kritis dan melakukan evaluasi); (7) Cultural and social understanding (pemahaman kultur sosial); dan (8) E-safety (keamanan) (Hague \& Payton, 2011).

Mengingat pentingnya literasi digital dalam menentukan keberhasilan belajar mahasiswa, maka kemampuan literasi digital perlu dikembangkan dalam rangka menghadapi era revolusi industri 4.0. Berdasarkan permasalahan yang telah diuraikan, maka tujuan penelitian untuk mengetahui bagaimana kemampuan literasi digital mahasiswa Program Studi Pendidikan Matematika Fakultas Keguruan dan Ilmu pendidikan Universitas Muhammadiyah Kotabumi, Lampung.

\section{METODE}

Metode penelitian yang digunakan adalah deskriptif kuantitatif. Populasi penelitian adalah seluruh mahasiswa semester 7 Program Studi Pendidikan Matematika Fakultas Keguruan dan Ilmu pendidikan Universitas Muhammadiyah Kotabumi tahun akademik 2020/2021 sebanyak 41 orang. Teknik sampling yang digunakan adalah simple random sampling. Pengambilan sampel dilakukan dengan kocok arisan, sehingga diperoleh sampel penelitian sebanyak 30 responden.

Instrumen pengumpul data menggunakan angket kemampuan literasi digital. Butir angket kemampuan literasi digital disusun berdasarkan 8 komponen literasi digital (Hague \& Payton, 2011). Skor penilaian angket menggunakan skala Likert 1-6. Adapun pilihan jawaban setiap butir pernyataan yaitu: STT = Sangat Tidak Tahu; TT = Tidak Tahu; TS = Tidak Setuju; KS = Kurang Setuju; S = Setuju; dan SS = Sangat Setuju. 
Tabel 1 Kisi-Kisi Angket Kemampuan Literasi Digital

\begin{tabular}{|c|c|c|}
\hline Komponen & Indikator & $\begin{array}{c}\text { Butir } \\
\text { Pernyataan }\end{array}$ \\
\hline $\begin{array}{l}\text { Functional skill } \\
\text { and beyond }\end{array}$ & $\begin{array}{l}\text { Kemampuan menggunakan komputer dan } \\
\text { memanfaatkan internet. }\end{array}$ & 1,2 \\
\hline Creativity & $\begin{array}{l}\text { Kreatif dalam menyajikan materi kelompok } \\
\text { menggunakan media digital; Kemampuan } \\
\text { berpikir kreatif dan imajinatif dalam } \\
\text { merencanakan dan mengeksplorasi ide. }\end{array}$ & $3,4,5$ \\
\hline Collaboration & $\begin{array}{l}\text { Kemampuan berpartisipasi di ruang digital; } \\
\text { Mampu memahami dan menjelaskan } \\
\text { gagasan-gagasan ke orang lain di ruang } \\
\text { digital. }\end{array}$ & $6,7,8$ \\
\hline Communication & $\begin{array}{l}\text { Mampu berkomunikasi melalui media } \\
\text { teknologi digital; Kemampuan memahami } \\
\text { dan mengerti orang lain di ruang digital. }\end{array}$ & $9,10,11$ \\
\hline $\begin{array}{l}\text { The ability to } \\
\text { find and select } \\
\text { infomation }\end{array}$ & $\begin{array}{l}\text { Kemampuan mencari dan menyeleksi } \\
\text { informasi. }\end{array}$ & 12,13 \\
\hline $\begin{array}{l}\text { Critical thinking } \\
\text { and evaluation }\end{array}$ & $\begin{array}{l}\text { Mampu berkontribusi, menganalisis, dan } \\
\text { berpikir kritis saat berhadapan dengan suatu } \\
\text { informasi. }\end{array}$ & $14,15,16$ \\
\hline $\begin{array}{l}\text { Cultural and } \\
\quad \text { social } \\
\text { understanding }\end{array}$ & $\begin{array}{l}\text { Pemahaman mengenai konteks sosial dan } \\
\text { budaya. }\end{array}$ & 17 \\
\hline E-safety & $\begin{array}{l}\text { Memahami keamanan saat bereksplorasi, } \\
\text { berkreasi, dan berkolaborasi dengan } \\
\text { teknologi digital. }\end{array}$ & $18,19,20$ \\
\hline
\end{tabular}

Analisis dilakukan pada setiap komponen literasi digital. Mengingat skor maksimum setiap butir angket adalah 6 dan setiap komponen literasi digital memiliki jumlah pernyataan yang beragam, maka untuk memperoleh rata-rata skor setiap komponen menggunakan rumus mean seperti terlihat pada rumus (1) (Sudjana, 1975).

$$
\bar{x}=\frac{\sum x}{n}
$$

Keterangan: $\bar{x}$ adalah rata-rata skor setiap komponen; $X_{i}$ adalah jumlah setiap butir pernyataan pada masing-masing komponen; $\mathrm{n}$ adalah banyaknya butir pernyataan setiap komponen. 
Edukasi: Jurnal Pendidikan, Volume 19 Nomor 1 Tahun 2021

Analisis Kemampuan Literasi Digital Mahasiswa

Karsoni Berta Dinata

Halaman 105-119

Penentuan nilai dalam interval 1-100 dengan melakukan konversi skor ratarata setiap komponen, seperti terlihat pada rumus (2) (Sudjana, 1975).

$$
\text { Nilai }=\frac{\bar{x}}{180} \times 100
$$

Keterangan: $\bar{x}$ adalah rata-rata skor setiap komponen.

Kategori penilaian setiap komponen literasi digital ditentukan menggunakan kriteria seperti pada Tabel 2 (Arikunto, 2010).

Tabel 2 Kategori Penilaian

\begin{tabular}{cc}
\hline Interval Nilai & Kategori Penilaiaan \\
\hline $81-100$ & Sangat Baik \\
$61-80$ & Baik \\
$41-60$ & Cukup Baik \\
$21-40$ & Kurang Baik \\
$0-20$ & Sangat Kurang \\
\hline
\end{tabular}

Penentuan nilai rata-rata kemampuan literasi digital dihitung berdasarkan rumus (3) (Arikunto, 2010).

$$
\text { Nilai }=\frac{1}{120} \frac{\sum Y}{30} \times 100
$$

Keterangan: $\sum Y$ adalah jumlah skor responden.

\section{HASIL DAN PEMBAHASAN}

\section{Functional Skill and Beyond}

Hasil jawaban responden mengenai komponen functional skill and beyond terlihat pada Gambar 1.

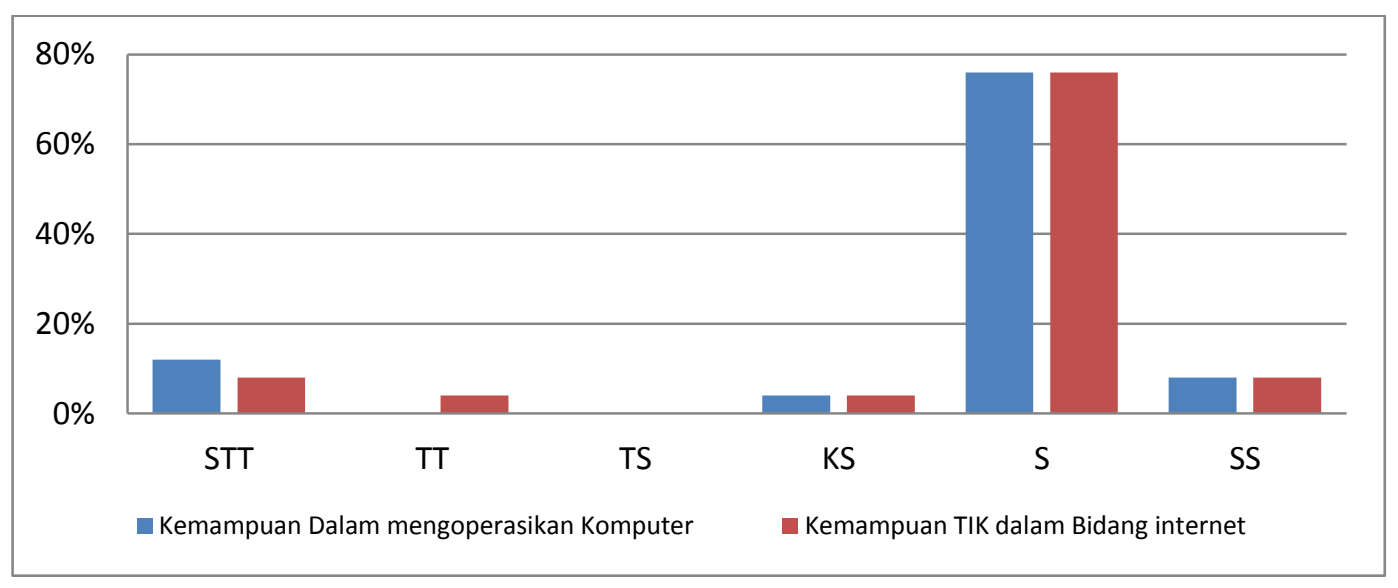

Gambar 1 Jawaban Komponen Functional Skill and Beyond 
Gambar 1 menunjukkan bahwa mayoritas responden menyatakan "Setuju" terkait kemampuan pada komponen functional skill and beyond. Jika data responden pada komponen functional skill and beyond dilakukan analisis menggunakan rumus rata-rata dalam komponen literasi digital, maka nilai yang diperoleh untuk komponen functional skill and beyond adalah 82. Nilai 82 selanjutnya dilakukan konversi menggunakan Kategori Penilaian (Tabel 2), sehingga diperoleh kategori penilaian pada komponen functional skill and beyond adalah "Sangat Baik".

Berdasarkan hasil tersebut, maka disimpulkan bahwa responden memiliki kemampuan yang sangat baik dalam mengoperasikan komputer serta memiliki kemampuan TIK dalam bidang internet pada komponen functional skill and beyond. Generasi milenial memiliki keterampilan dalam mengoperasikan komputer dan mengakses internet yang baik. Hal tersebut wajar, mengingat hampir semua mahasiswa memiliki smartphone dan menghabiskan sebagian besar waktunya untuk internetan (Kurniawati \& Baroroh, 2016; Rahmadani, 2020).

\section{Creativity}

Hasil jawaban responden mengenai komponen creativity terlihat pada Gambar 2.

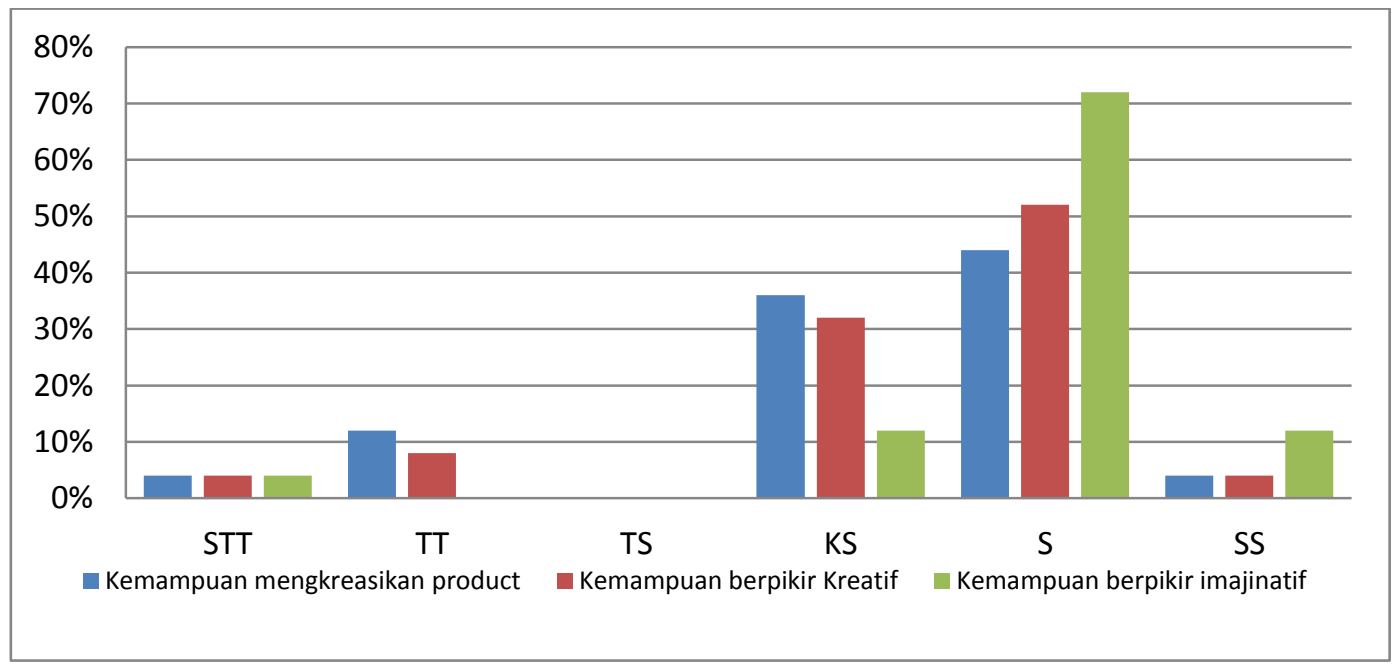

Gambar 2 Jawaban Komponen Creativity 
Edukasi: Jurnal Pendidikan, Volume 19 Nomor 1 Tahun 2021

Analisis Kemampuan Literasi Digital Mahasiswa

Karsoni Berta Dinata

Halaman 105-119

Gambar 2 menunjukkan bahwa mayoritas responden menyatakan "Setuju" terkait kemampuan pada komponen creativity. Jika data responden pada komponen creativity dilakukan analisis menggunakan rumus rata-rata dalam komponen literasi digital, maka nilai yang diperoleh untuk komponen creativity adalah 69. Nilai 69 selanjutnya dilakukan konversi menggunakan Kategori Penilaian (Tabel 2), sehingga diperoleh kategori penilaian pada komponen creativity adalah "Baik".

Berdasarkan hasil tersebut, maka disimpulkan bahwa responden memiliki kemampuan yang baik dalam berpikir kreatif, imajinatif, dan menghasilkan suatu produk. Namun demikian, berdasarkan hasil jawaban responden, cukup banyak yang menyatakan "Kurang Setuju". Hasil tersebut menunjukkan bahwa kemampuan atau tingkat kreativitas mahasiswa belum dikembangkan secara optimal. Mahasiswa masih mengalami kesulitan untuk berpikir kreatif dalam menyajikan materi kelompok secara sistematis dan menarik dengan menggunakan berbagai aplikasi digital. Hal tersebut sangat disayangkan, mengingat kreativitas sangat berperan dalam menentukan keberhasilan belajar peserta didik (Dinata, 2016; Resti, 2015; Subur, 2013).

\section{Collaboration}

Hasil jawaban responden mengenai komponen collaboration terlihat pada Gambar 3. Gambar 3 menunjukkan bahwa mayoritas responden menyatakan "Setuju" terkait kemampuan pada komponen collaboration. Jika data responden pada komponen collaboration dilakukan analisis menggunakan rumus rata-rata dalam komponen literasi digital, maka nilai yang diperoleh untuk komponen creativity adalah 68. Nilai 68 selanjutnya dilakukan konversi menggunakan Kategori Penilaian (Tabel 2), sehingga diperoleh kategori penilaian pada komponen collaboration adalah "Baik".

Berdasarkan hasil tersebut, maka disimpulkan bahwa responden memiliki kemampuan yang baik dalam menjelaskan gagasan dan berpartisipasi di ruang digital. Namun demikian, responden selama di ruang digital (misalkan Zoom) lebih nyaman dengan hanya mendengarkan dan mematikan video daripada harus 
aktif berpartisipasi, bahkan menjelaskan suatu gagasan. Oleh karenya, beberapa cara yang bisa digunakan untuk meningkatkan kemampuan kolaborasi mahasiswa yaitu penggunaan model pembelajaran Problem-Based Learning (Fitriyani et al., 2019; Nurhayati et al., 2019) dan model kolaborasi (Pratiwi, 2015).

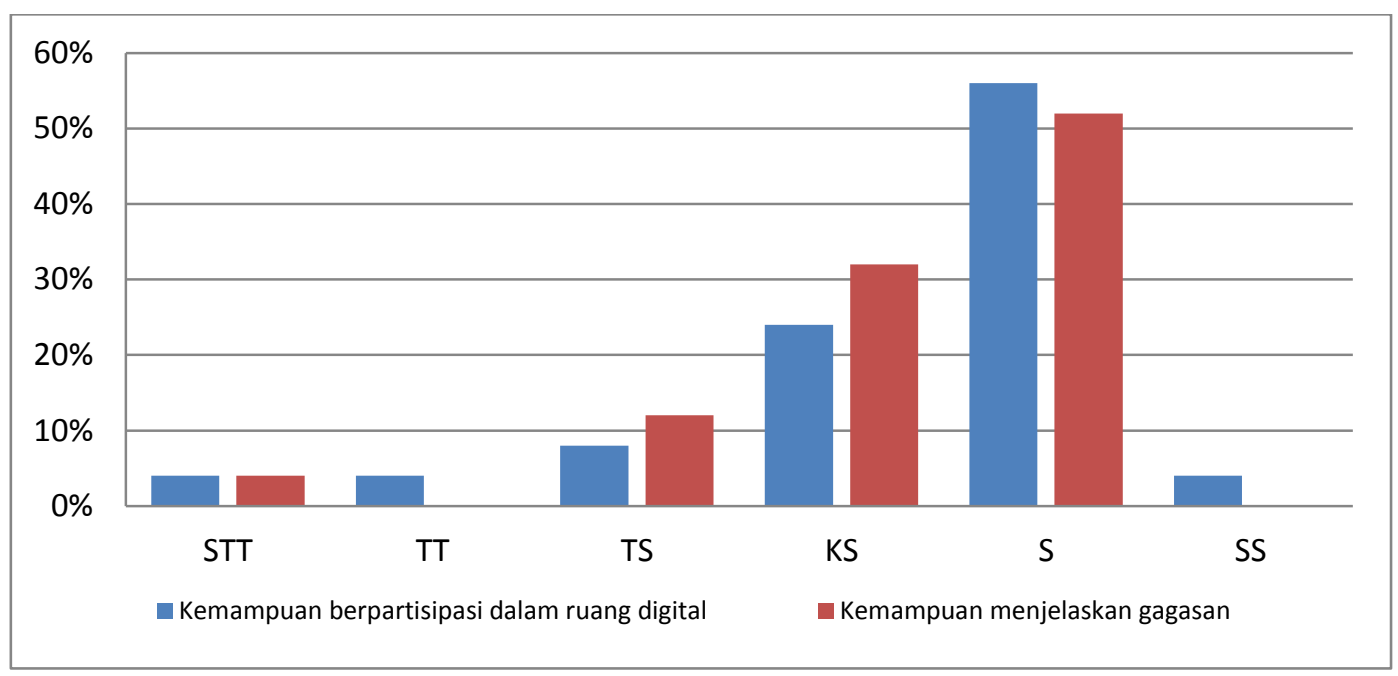

Gambar 3 Jawaban Komponen Collaboration

\section{Communication}

Hasil jawaban responden mengenai komponen communication terlihat pada Gambar 4.

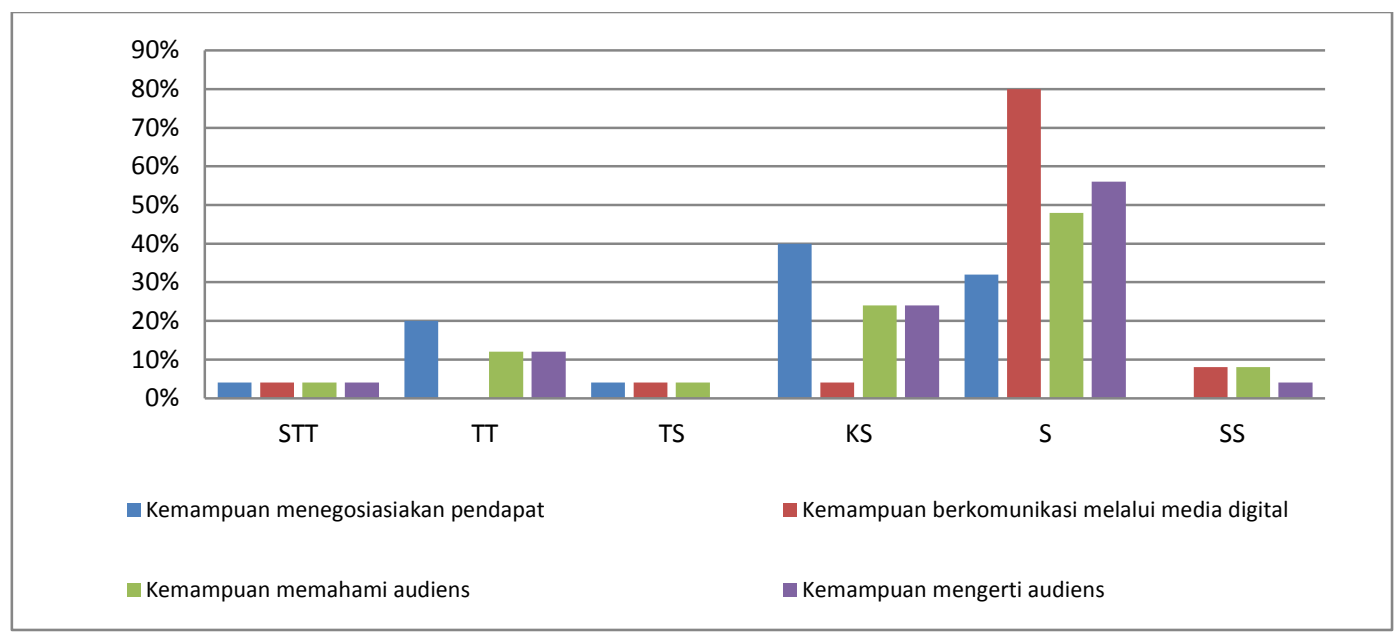

Gambar 4 Jawaban Komponen Communication

Gambar 4 menunjukkan bahwa mayoritas responden menyatakan "Setuju" terkait kemampuan pada komponen communication. Jika data responden pada 
Edukasi: Jurnal Pendidikan, Volume 19 Nomor 1 Tahun 2021

Analisis Kemampuan Literasi Digital Mahasiswa

Karsoni Berta Dinata

Halaman 105-119

komponen communication dilakukan analisis menggunakan rumus rata-rata dalam komponen literasi digital, maka nilai yang diperoleh untuk komponen communication adalah 73 . Nilai 73 selanjutnya dilakukan konversi menggunakan Kategori Penilaian (Tabel 2), sehingga diperoleh kategori penilaian pada komponen communication adalah "Baik".

Berdasarkan hasil tersebut, maka disimpulkan bahwa responden memiliki kemampuan yang baik dalam berkomunikasi melalui media digital, menegosiasi pendapat, dan memahami orang lain. Kemampuan komunikasi yang baik oleh responden tidak terlepas dari kebiasaan responden dalam menggunakan smartphone sebagai alat komunikasi, sehingga responden terbiasa serta berani menyampaikan gagasan sendiri dan mendengar gagasan orang lain melalui media digital. Temuan penelitian mendukung hasil penelitian terdahulu yang menyatakan bahwa respons responden pada kategori advance yang berarti kemampuan menggunakan media sangat tinggi (Perwita, 2021).

\section{The Ability to Find and Select Infomation}

Hasil jawaban responden mengenai komponen the ability to find and select infomation terlihat pada Gambar 5.

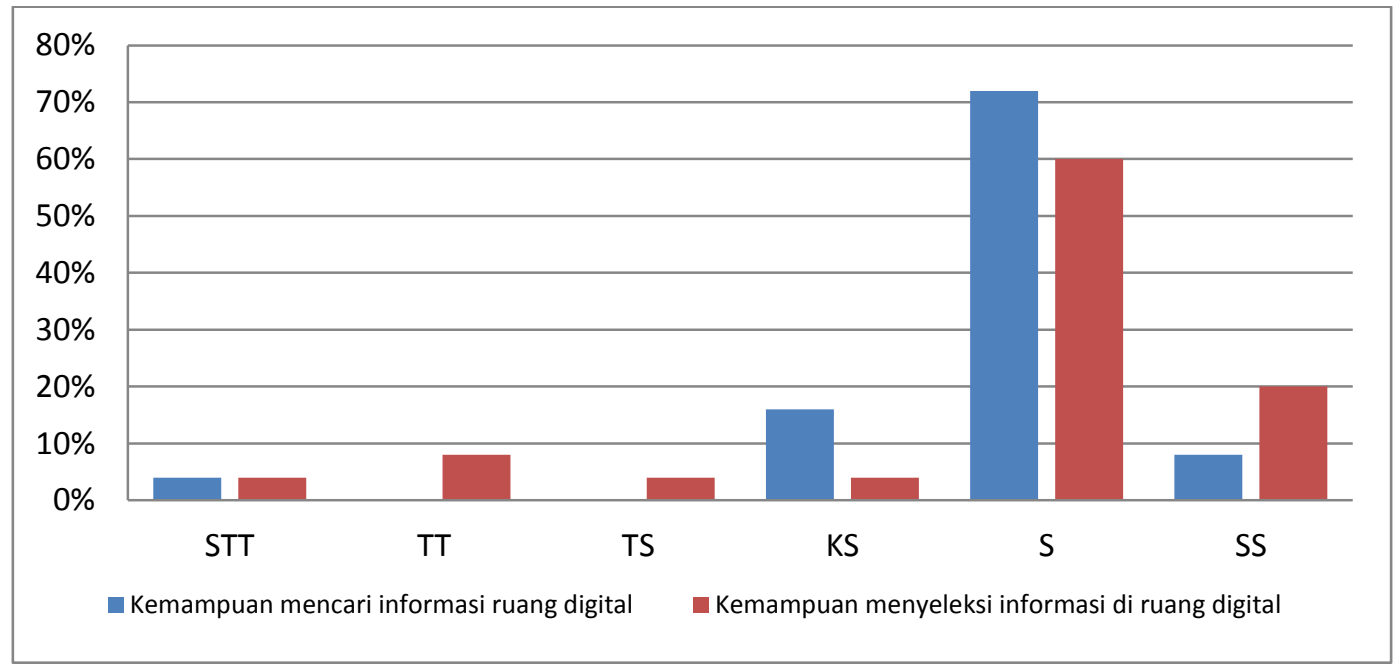

Gambar 5 Jawaban Komponen The Ability to Find and Select Infomation

Gambar 5 menunjukkan bahwa mayoritas responden menyatakan "Setuju" terkait kemampuan pada komponen the ability to find and select information. Jika 
data responden pada komponen communication dilakukan analisis menggunakan rumus rata-rata dalam komponen literasi digital, maka nilai yang diperoleh untuk komponen communication adalah 79. Nilai 79 selanjutnya dilakukan konversi menggunakan Kategori Penilaian (Tabel 2), sehingga diperoleh kategori penilaian pada komponen communication adalah "Baik".

Berdasarkan hasil tersebut, maka disimpulkan bahwa responden memiliki kemampuan yang baik dalam mencari informasi dan menyeleksi informasi di ruang digital. Mahasiswa memang memiliki kemampuan yang baik dalam mencari informasi, tetapi mahasiswa masih kurang efisien menemukan informasi yang diperlukan (Maretina, 2016).

\section{Critical Thinking and Evaluation}

Hasil jawaban responden mengenai komponen critical thinking and evaluation terlihat pada Gambar 6.

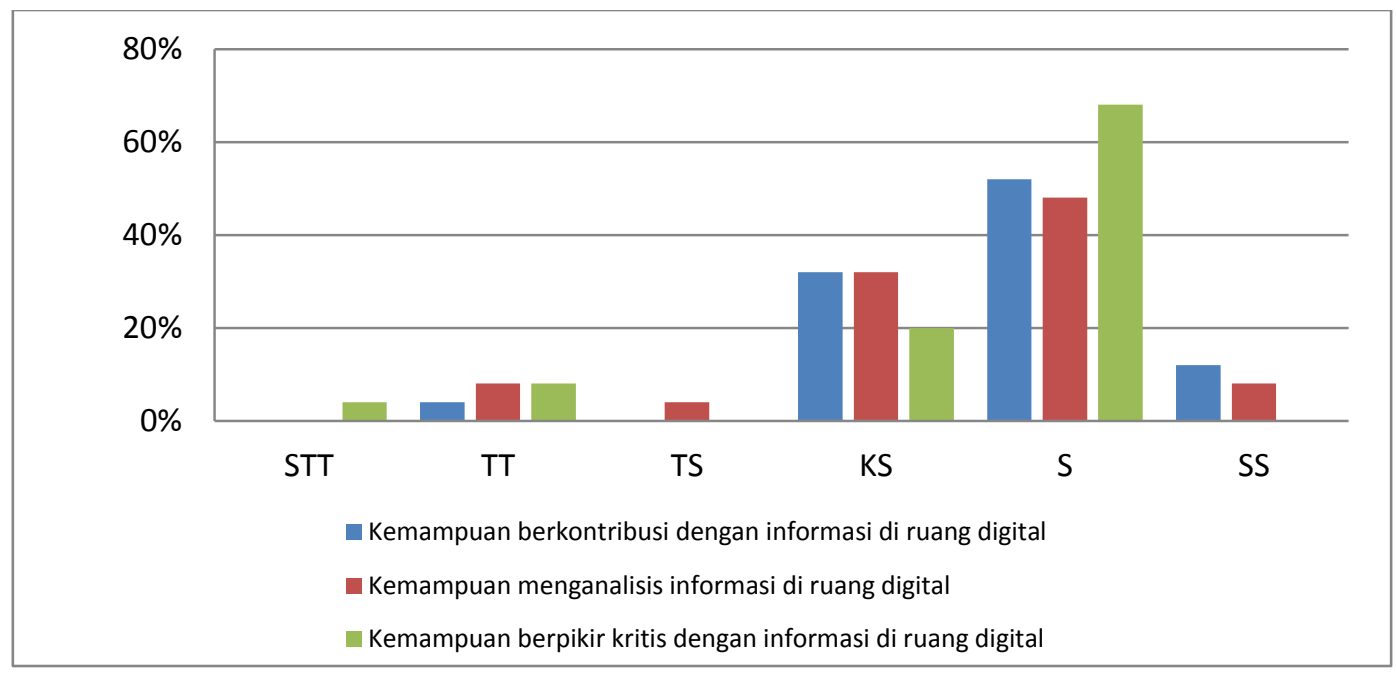

Gambar 6 Jawaban Komponen Critical Thinking and Evaluation

Gambar 6 menunjukkan bahwa mayoritas responden menyatakan "Setuju" terkait dengan kemampuan pada komponen critical thinking and evaluation. Jika data responden pada komponen critical thinking and evaluation dilakukan analisis menggunakan rumus rata-rata dalam komponen literasi digital, maka nilai yang diperoleh untuk komponen critical thinking and evaluation adalah 79. Nilai 79 selanjutnya dilakukan konversi menggunakan Kategori Penilaian (Tabel 2), 
Edukasi: Jurnal Pendidikan, Volume 19 Nomor 1 Tahun 2021

Analisis Kemampuan Literasi Digital Mahasiswa

Karsoni Berta Dinata

Halaman 105-119

sehingga diperoleh kategori penilaian pada komponen critical thinking and evaluation adalah "Baik". Berdasarkan hasil tersebut, maka disimpulkan bahwa responden memiliki kemampuan yang baik dalam menganalisis dan berpikir kritis terhadap informasi yang ada. Mahasiswa mampu mengevaluasi kualitas hasil pencarian untuk menentukan kegunaannya dalam proses pencarian, keandalan isi informasinya, serta keandalan sumbernya (Maretina, 2016).

\section{Cultural and Social Understanding}

Hasil jawaban responden mengenai komponen cultural and social understanding terlihat pada Gambar 7.

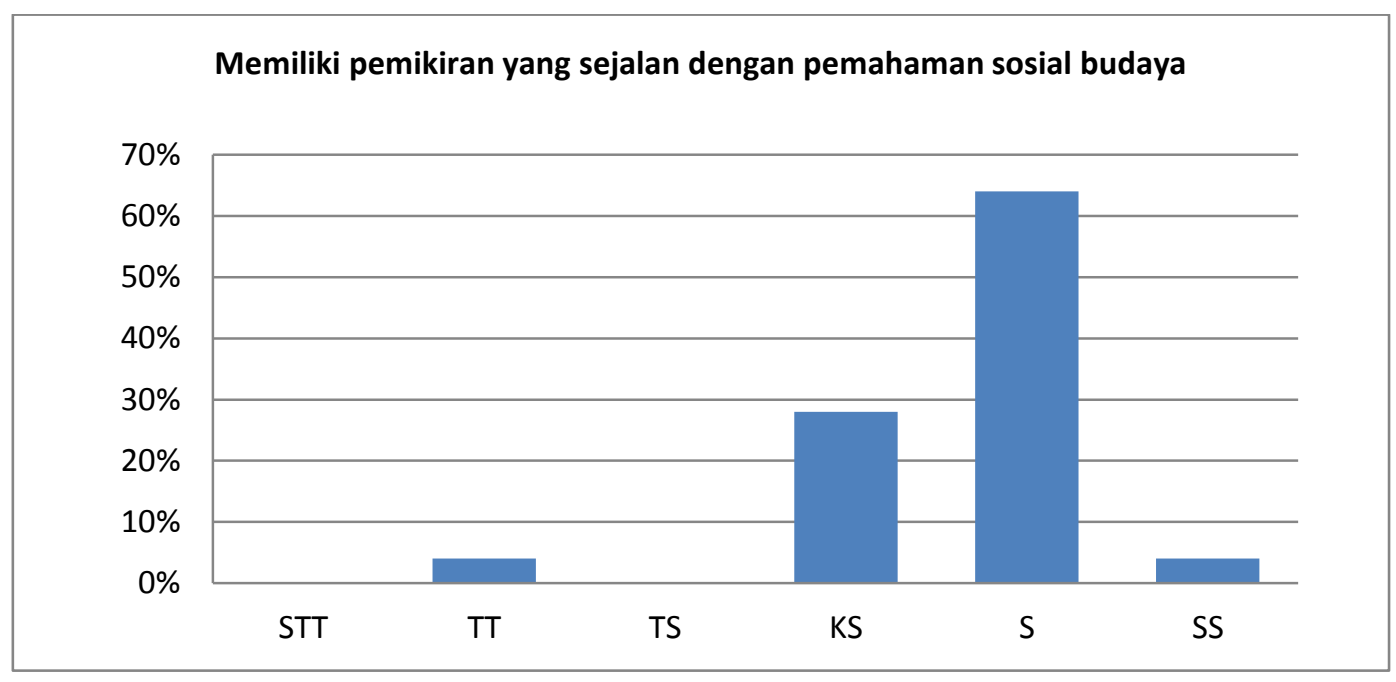

Gambar 7 Jawaban Komponen Cultural and Social Understanding

Gambar 7 menunjukkan bahwa mayoritas responden menyatakan "Setuju" terkait kemampuan pada komponen cultural and social understanding. Jika data responden pada komponen cultural and social understanding dilakukan analisis menggunakan rumus rata-rata dalam komponen literasi digital, maka nilai yang diperoleh untuk komponen cultural and social understanding adalah 77. Nilai 77 selanjutnya dilakukan konversi menggunakan Kategori Penilaian (Tabel 2), sehingga diperoleh kategori penilaian pada komponen cultural and social understanding adalah "Baik".

Berdasarkan hasil tersebut, maka disimpulkan bahwa responden memiliki kemampuan yang baik dalam menyelaraskan informasi di ruang digital dengan 
konteks pemahaman sosial-budaya. Nilai-nilai budaya menjadi benteng dalam menyelaraskan informasi di ruang digital dengan konteks pemahaman sosialbudaya (Pranoto \& Wibowo, 2018).

\section{E-Safety}

Hasil jawaban responden mengenai komponen $e$-safety terlihat pada Gambar 8. Gambar 8 menunjukkan bahwa mayoritas responden menyatakan "Setuju" terkait kemampuan pada komponen e-safety. Jika data responden pada komponen e-safety dilakukan analisis dengan menggunakan rumus rata-rata dalam komponen literasi digital, maka nilai yang diperoleh untuk komponen $e$-safety adalah 67.

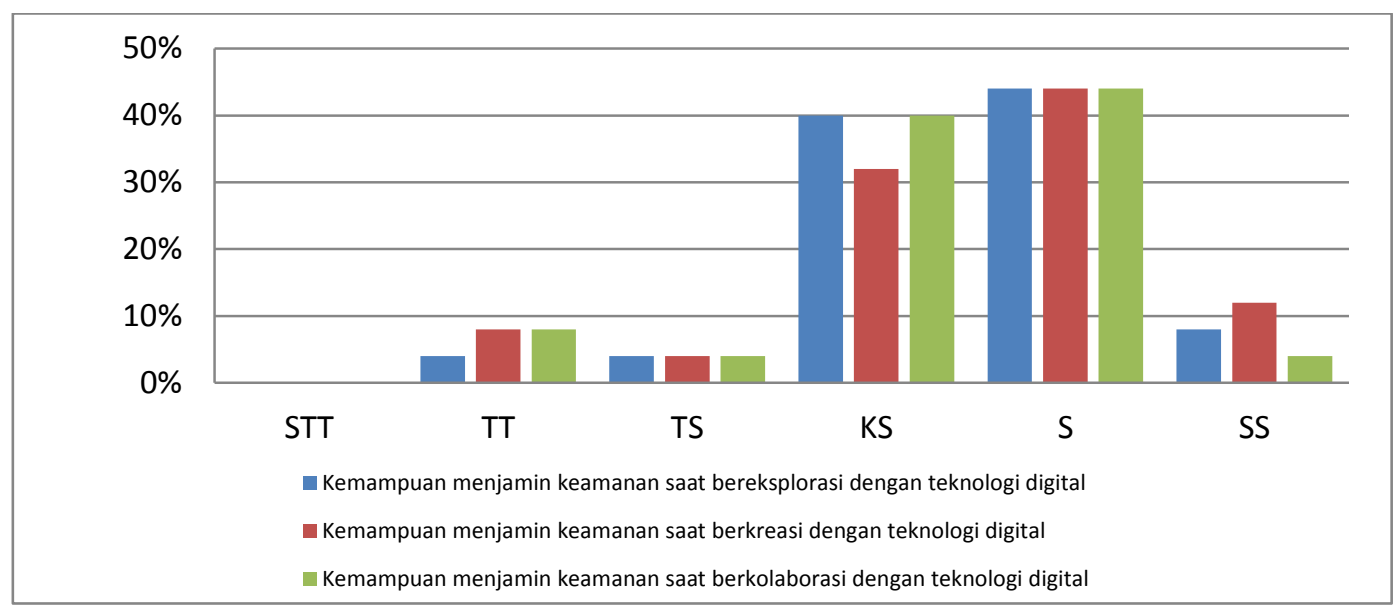

\section{Gambar 8 Jawaban Komponen E-Safety}

Nilai 67 selanjutnya dilakukan konversi menggunakan Kategori Penilaian (Tabel 2), sehingga diperoleh kategori penilaian pada komponen e-safety adalah "Baik". Berdasarkan hasil tersebut, maka disimpulkan bahwa responden memiliki kemampuan yang baik dalam bereksplorasi, berkreasi, dan berkolaborasi dengan teknologi digital. Temuan penelitian mendukung hasil penelitian terdahulu yang menyatakan persentase tingkat literasi digital untuk komponen safety berada pada kategori baik (Nada \& Sari, 2020).

\section{SIMPULAN}

Data dikumpulkan dan dianalisis berdasarkan pada 8 komponen dalam literasi digital. Hasil analisis data penelitian menunjukkan bahwa kemampuan 
Edukasi: Jurnal Pendidikan, Volume 19 Nomor 1 Tahun 2021

Analisis Kemampuan Literasi Digital Mahasiswa

Karsoni Berta Dinata

Halaman 105-119

responden untuk komponen functional skill and beyond dalam literasi digital berada pada kategori "Sangat Baik", sedangkan untuk ketujuh komponen literasi digital lainnya berada pada kategori "Baik". Berdasarkan hasil tersebut, maka disimpulkan bahwa kemampuan literasi digital mahasiswa Program Studi Pendidikan Matematika Fakultas Keguruan dan Ilmu Pendidikan Universitas Muhammadiyah Kotabumi berada pada kategori "Baik".

\section{DAFTAR PUSTAKA}

Arikunto, S. (2010). Prosedur Penelitian Suatu Pendekatan Praktis. Jakarta: Renika Cipta.

Dinata, K. B. (2020). Problematika pembelajaran daring mata kuliah Geometri Transformasi di masa pandemi COVID-19. Eksponen, 10(2), 50-58. https://doi.org/10.47637/eksponen.v10i2.296.

Dinata, K. B. (2016). Eksperimentasi model pembelajaran kooperatif tipe Student Teams Achievement Division (STAD) dan Jigsaw dengan pendekatan Pendidikan Matematika Realistik (PMR) pada materi Relasi dan Fungsi siswa kelas VIII SMP Negeri Kabupaten Lampung Utara tahun pelajaran 2015/2016 ditinjau dari kreativitas belajar Matematika. Disertasi: Universitas Sebelas Maret. Tidak dipublikasikan.

Dwi, B., Amelia, A., Hasanah, U., \& Putra, A. M. (2020). Analisis keefektifan pembelajaran online di masa pandemi COVID-19. Jurnal Pendidikan Guru Sekolah Dasar, 2(1), 28-37.

Elpira, B. (2018). Pengaruh penerapan literasi digital terhadap peningkatan pembelajaran siswa di SMP Negeri 6 Banda Aceh. Disertasi: UIN ArRaniry Banda Aceh. Tidak dipublikasikan.

Fadila, R., Nadiroh, T., Juliana, R., Zulfa, P., \& Ibrahim, I. (2021). Kemandirian belajar secara daring sebagai prediktor hasil belajar mahasiswa Pendidikan Matematika UIN Sunan Kalijaga. Jurnal Cendekia: Jurnal Pendidikan Matematika, 5(2), 880-891. https://doi.org/10.31004/cendekia.v5i2.457.

Fatmawati, E., \& Safitri, E. (2020). Kemampuan literasi informasi dan teknologi mahasiswa calon guru menghadapi pembelajaran di era revolusi industri 4.0. 
Edukasi: Jurnal Pendidikan, 18(2), 214-224. http://dx.doi.org/10.31571/ edukasi.v18i2.1863.

Fitriyani, D., Jalmo, T., \& Yolida, B. (2019). Penggunaan Problem Based Learning untuk meningkatkan keterampilan kolaborasi dan berpikir tingkat tinggi. Jurnal Bioterdidik: Wahana Ekspresi Ilmiah, 7(3), 77-87.

Gilster, P., \& Watson, T. (1999). Digital literacy. New York: Wiley Computer Pub.

Hague, S., \& Payton, S. (2011). Digital literacy across the curriculum. Curriculum \& Leadership Journal, 9(10), 1-10.

Kemendikbud. (2017). Materi Pendukung Literasi Digital. Jakarta: Kemendikbud.

Kurniawati, J., \& Baroroh, S. (2016). Literasi media digital mahasiswa Universitas Muhammadiyah Bengkulu. Jurnal Komunikator, 8(2), 51-66.

Maretina, S. (2016). Digital information fluency pada mahasiswa Universitas Airlangga. Skripsi: Universitas Airlangga. Tidak dipublikasikan.

Nada, E. I., \& Sari, W. K. (2020). Analisis literasi digital calon guru Kimia dalam pelaksanaan PPL berbasis virtual di masa pandemi COVID-19. ORBITAL: Jurnal Pendidikan Kimia, 4(2), 111-121. https://doi.org/10.19109/ ojpk.v4i2.6704.

Nurcahyo, M. A. (2020). Penggunaan multimedia interaktif untuk meningkatkan literasi digital siswa SMP pada mata pelajaran IPA. Jurnal Pendidikan Informatika dan Sains, 9(2), 132-138. http://dx.doi.org/10.31571/ saintek.v9i2.2077.

Nurhayati, D. I., Yulianti, D., \& Mindyarto, B. N. (2019). Bahan ajar berbasis Problem Based Learning pada materi Gerak Lurus untuk meningkatkan kemampuan komunikasi dan kolaborasi siswa. UPEJ Unnes Physics Education Journal, 8(2), 208-218. https://doi.org/10.15294/upej.v8i2.33333.

Perwita, D. (2021). Literasi media digital mahasiswa Universitas Jenderal Soedirman. EQUILIBRIUM: Jurnal Ilmiah Ekonomi dan Pembelajarannya,9(1), 8-13. http://doi.org/10.25273/equilibrium.v9i1. 8515.

Pratiwi, I. A. (2015). Pengembangan model kolaborasi Jigsaw Role Playing 
Edukasi: Jurnal Pendidikan, Volume 19 Nomor 1 Tahun 2021

Analisis Kemampuan Literasi Digital Mahasiswa

Karsoni Berta Dinata

Halaman 105-119

sebagai upaya peningkatan kemampuan bekerjasama siswa kelas V SD pada pelajaran IPS. Jurnal Konseling Gusjigang, 1(2), 1-11. https://doi.org/ 10.24176/jkg.v1i2.411.

Putria, H., Maula, L. H., \& Uswatun, D. A. (2020). Analisis proses pembelajaran dalam jaringan (daring) masa pandemi COVID-19 pada guru sekolah dasar. Jurnal Basicedu, 4(4), 861-870. https://doi.org/10.31004/basicedu.v4i4.460.

Rahmadani, H. (2020). Profil keterampilan literasi digital: Penelitian survey di SMA IT Al Bayyinah Pekanbaru. Instructional Development Journal, 3(2), 96-103. http://dx.doi.org/10.24014/idj.v3i2.11306.

Resti, V. D. A. (2015). Analisis kreativitas mahasiswa dalam penyusunan Peta Konsep berbentuk E-Mind Map berdasarkan kajian neurosains. Jurnal Pendidikan Biologi, 6(2), 128-134. http://dx.doi.org/10.17977/ um052v6i2p128-134.

Subur, J. (2013). Analisis kreativitas siswa dalam memecahkan masalah matematika berdasarkan tingkat kemampuan matematika di kelas. Jurnal Penelitian Pendidikan,13(1), 113-126. https://doi.org/10.17509/jpp. v13i1.3478.

Sudjana. (1975). Metoda Statistika. Bandung: Tarsito.

Pranoto, H., \& Wibowo, A. (2018). Identifikasi nilai kearifan lokal (local wisdom) Piil Pesenggiri dan perannya dalam pelayanan konseling lintas budaya. Jurnal bimbingan konseling Indonesia,3(2), 36-42. http://dx.doi.org/10.26737/jbki.v3i2.714.

Sujana, A., \& Rachmatin, D. (2019). Literasi digital abad 21 bagi mahasiswa PGSD: Apa, mengapa, dan bagaimana. Current Research in Education: Conference Series Journal, 1(1), 003-013. 